\title{
COMMERCIAL POTENTIAL AND READINESS OF THE LAO NATIONAL CONVENTION CENTER TO SUPPORT MICE INDUSTRY
}

\author{
Vilakone Phanthanousy and Suteera Sribenjachot \\ Business Administration Department, Faculty of Business Administration, \\ North - Chiang Mai University, Thailand
}

\begin{abstract}
This constructivist research in which case study method was used as the strategy inquiry aimed to study the potential, readiness and current state of management of the Lao National Convention Center (LNCC). The analysis and assessment of environment is a mean for devising strategic management framework of LNCC to support MICE industry. Key informants chosen by the author using purposive sampling method were: 1) those who devising policies and strategies, plans, programs and other activities involving special economic zone development, 2) those playing role in supporting the development and promotion, 3) beneficiary of strategic development, and 4) scholars and consultants with knowledge and experience in special economic zone development. According to research results, to be a revenue-generating agency and to enable efficient and full resource usage (venue, human resource and budget) in the midst of changes of environment of tough competition at the national level, LNCC had to use its strengths and opportunities as well as to reduce possible limitations or obstacles. All these focused on strategic management, managerial planning and systematic formulation of strategies. Such strategies were then implemented under activities and programs, which were consistent with plans. Also, the control was taken before, during and after operations in order to steer them in the direction that emphasized on the use of organizational resources in all activities and actions of different units in the organization for the achievement of maximum benefits.
\end{abstract}

Key words: Commercial, Lao National Convention Center, MICE, Potential, Readiness

Cite this Article: Vilakone Phanthanousy and Suteera Sribenjachot, Commercial Potential and Readiness of the Lao National Convention Center to Support MICE Industry, International Journal of Management, 11(12), 2020, pp 931-938.

http://iaeme.com/Home/issue/IJM?Volume=11\&Issue=12 


\section{INTRODUCTION}

Tourism is a service industry that plays a crucial role in economic development of many countries worldwide so the governments attach great importance to fostering the competitiveness for gaining world tourism market share. Asian and ASEAN countries, for example, have introduced marketing strategies to attract more global tourists to visit their countries. World Tourism Organization (UNWTO) predicts a growing number of tourists that there will be 1.6 billion international tourists by 2020 (UNWTO, 2016). Tourism is thus the harmonized with the country's development of all industries and dimensions and integrated in national development strategies and as a part of economic development. Besides, a clear national development strategy based on strong economy, great infrastructure, rich natural resource and potential tourism personnel is a key factor in promoting the country's development of competitive advantage and steady tourism growth. Likewise, the focus of the Lao government on rapidly growing trend of tourism is reflected in its $7^{\text {th }}$ and $8^{\text {th }}$ Five-Year Economic and Social Development Plans (2011-2015 and 2016-2020, respectively) and policies of the Ministry of Information, Culture and Tourism. All these aim at enhancement of continual growth of tourism. As a result, the economic development in related businesses or industries is a direction, which the government has implemented and promoted for the efficient integration of national development. The Lao government gives importance to MICE industry that because it is one of tourism industry sectors for travelers with specific purpose: to engage in activities of a business enterprise or corporate, namely, Meeting (M) of an organization, Incentive (I) Tourism, International Convention (C) and Trade Exhibition (E). MICE industry is able to steer national economy and bring high-quality tourists into the country generating a high job and income. At present, various countries (e.g. Japan, China, Korea, Thailand, Singapore, and Lao PDR) recognize MICE as a service industry, which becomes one of its main industries (International Congress and Convention Association, 2018).

Lao PDR hosted the Asia-Europe Meeting (ASEM) in 6-9 October 2012 with 43 member countries including 16 Asian countries (10 ASEAN nations, China, India, Japan, Mongolia, Pakistan and South Korea,), 27 EU member countries and 2 organizations (the European Commission and the ASEAN Secretariat). ASEM Meeting aims to foster mutual familiarity; to have a broad discussion on common interests; and to build Asia-Europe cooperation in terms of politics, economy, society and culture. The Lao government built LNCC for the said meeting and it was designated the same status as a department under the Office of the Prime Minister of Lao PDR. Its operating income (approximate service income of 30 million Baht per year) is delivered to the Ministry of Finance, while its expenses are from state budget. The government now focuses on its management to generate income in the midst of changing direction of highly competitive environment at national level. However, LNCC lacks operational direction so its management fails to achieve full and efficient use of resources, venue, human resources and budgets. (Office of the Prime Minister of Lao PDR, 2017)

The holistic management approach is required for the efficient convention center management to support the growth of tourism and MICE industry, which generate income to the country. Ramberg et al., (2015) describes MICE venue management model in 4 aspects: 1) amenities, 2) accessibility, 3) risk and safety management and 4) onsite management. This is in line with Theng (2019) who mentions that MICE venue management consists of 5 areas: 1) comfort of clients focusing on management of their feelings to create the impression e.g. cleanness, light and sound systems, internet access and surrounding atmosphere, etc. 2) convenience including preparation and management of public transport for accessibility of all visitors and stakeholders, 3) safety and security implying the knowledge of laws and regulations, safety standards and contact and coordination with government or other relevant 
agencies, 4) administration by organizers and supervisors in planning and management as well as checking and monitoring, and 5) sustainability management (Ramsborg et al., 2015; Theng, 2018).

Therefore, the study of potentials, preparedness and state of management of LNCC to support MICE industry will help devise long-term policy, strategy and management in line with conditions, contexts and trends. This is a direction of changing environment and industry targeted for economic growth at the national and global level. Hence, MICE industry and tourism enhance efficient operations and potentials of LNCC in response to the creation of the country's competitiveness in a continual manner.

\section{RESEARCH METHODOLOGY}

The constructivist approach is used in this research due to the author's belief that the truth is intangible and derives from the individual's experiences. Moreover, the truth that the author wishes to know connect to the research finding context. The knowledge or truth will be made through an exchange of arguments. Also, the author uses a case study method as the strategy of inquiry because this research specifically aims at the management of LNCC. Its key informants are divided into 3 groups: 1) those who formulating policies and strategies, plans, programs and other activities involving special economic zone development, 2) those playing role in supporting the development and promotion or former executives in charge of public agencies/organizations or state-owned enterprises or private sector in the area of MICE industry and tourism policies in Lao PDR, and 3) other stakeholders including scholars and consultants with expertise, experience and knowledge in giving advices on the management of LNCC. The purposive sampling method is used in choosing a total of 12 persons from the above group according to qualitative research principle for determining key informant size (Guest, Bunce, \& Johnson, 2006; Kuzel, 1999, cited in B.Marshall et al., 2013). This is to obtain the data that most closely match the research purposes (Creswell, 2007). The research tools are interview forms, validated by experts in light of content validity and language use. In-depth interviews are also conducted due to the needs of in-depth, specific and suitable explanations in terms of qualitative approach (Creswell \& Clark, 2007). To sufficient data for analysis, the author uses documentary analysis to collect and explore the additional data from relevant domestic and international books, articles and research on the conference center strategy and management. SWOT Analysis (Wheelen \& Hunger, 2012) and five forces model of Michael E. Porter $(1985 ; 1990)$ are applied in analyzing the competitive industry situation of convention and exhibition centers so that research results can be most applicable to the context of LNCC. The author systemizes the data obtained from interviews by means of categorization and summarization for analysis purpose (Miles \& Huberman, 1984) to ensure the accuracy. With regard to rigor criteria, the triangulation of findings and interpretation of collected data are conducted for greater trustworthiness (Lincoln \& Guba, 1985).

\section{RESULTS AND DISCUSSIONS}

The study results of the management of LNCC are as follows:

Management Style: current management style of LNCC involves political services as the primary function, social function and other services. It is funded by the government and operated with the administrative structure equivalent to a department under the Office of the Prime Minister of Lao PDR. There is a committee in charge of its management and the Chief of Conference Center is equivalent to the Deputy Director General. LNCC is a source of income for the government.

Nature of Operation or Service Provision: it is a venue for activities and meetings of political entities and government at the national and international level and for meetings, activities and 
trade exhibitions of national and international entities in the field of economy, business and technology.

Readiness of Physical Structure, Management System and Service Provision: regarding the physical structure of LNCC, it is located in the suitable location close to city center and has a good security system. Its communication system, spacious parking area, meeting rooms, restaurants and toilets are adequate and meet the standard. This agrees with elements in the study of Ramberg et al., (2015). For the management systems and service provision, there is an agency responsible for its management and the personnel are contracted. The maintenance of cleanness and tidiness is outsourced.

Environmental Assessment of the Lao National Convention Center revealed the following strengths, weaknesses, opportunities and obstacles

Strengths: Physical Structure - apart from the venue's beauty in light of cultural identity, the venue and surrounding area are equipped with standard amenities: meeting rooms, restaurants, exhibition halls, toilets and adequate parking area. Management and organizing: the operational plan covering the whole organizing process is clearly devised in response to customers' needs, while the event organization is monitored to ensure the fulfillment of goals, objectives and plans. This is line with Theng's study (2019) in terms of planning and management. Marketing: the event organization designs are diverse and modern as well as respond to economic, social, political and technological conditions. Also, the amenities in Vientiane for domestic and international participants are full-service hotels to accommodate them and other activities (apart from the event) e.g. tourist attractions, socialization places, shopping centers and business opportunities to attract more visit to the event. Human resource management: the training courses, seminars and learning activities are held to enhance and develop potentials and quality of personnel in organizing meetings, expositions and trade exhibitions. Operation: for further improvement purpose, the service system is provided for clients and employers to comment any problems and obstacles after joining or working in the event. Furthermore, work standards are determined to control work quality in accordance with the established standards. Finance and budget: its management and operation are funded by the government.

Weakness: Physical Structural - there is less support for efficient use of energy and resource according to the needs and the suitability of activity and venue. Management and organizing: it has inconsistent management structure with organizational resources and lacks capacity-building to foster flexible organizational management. As it is a department under the Office of the Prime Minister of Lao PDR, professional management image must be created. Currently, there are no master plans for the development of the brand name of LNCC and of 'MICE of Lao PDR'. Marketing: it lacks the following: development or expansion of existing event organization styles into the new ones, pre- and post-event study of customer needs to obtain necessary information, exploration of possible gaps or opportunities to find the demand of clients or participants for organizing events, inspection (by public and private entities) of the quality of event organization for standards certification, customer relationship management system for communications between NLCC and clients and for offering new products or services, market opportunity assessment and competitor analysis for making the marketing plans and strategies to ensure the profitable and sustainable operation and good image of LNCC and, lastly, professional sales representatives (personnel or agencies) in sourcing and reaching the target market. Human resource management: local staffs in charge of service provision and operation of LNCC have a low level of expertise in organizing events. LNCC lacks the activity and system for human resource development and skill enhancement to support future growth and the recruitment of expert and knowledgeable staffs for the management of diverse LNCC staffs, customers or clients and event attendees. Operation: service quality, 
service provision, food and beverage service and staff's personality are uneven, while the use of innovations and new technologies in different stages of event organization for cost, labor and time saving is low. Finance and budget: it lacks systematic analysis and management of direct and indirect costs and the reduction or cutting of operating cost for higher profit margin and investment value assessment.

Opportunities: the accession to the ASEAN Economic Community is the trade, investment and tourism opportunities for Lao PDR, especially Vientiane, which is its capital city and center of government, politics and economy. The expectation of continual growth of domestic and international tourists is in line with the study of UNWTO (2016). Lao PDR is a politically stable country with peaceful and good cooperation with countries in Mekong region and worldwide. With long history, natural beauty and cultural diversity, Lao PDR is attractive to tourism and investment after it opens to international tourism. This steadily attracts investments of domestic and international business sectors (Spencer \& Bavuma, 2018). Besides, the Lao government attaches importance to tourism industry investments by determining that the tourism is one of 11 national development plans and that the country development in terms of tourism is the government's policy. Moreover, the Lao government is accepted and trusted at the ASEAN, Asian and international levels to host the meetings of alliance group and economic integration blocs. This promotes credibility and experience in holding events. The transport routes for connection across the country and with neighboring countries in the northern, central and southern parts is the infrastructure development along with the government's accelerated improvement of facilities and utilities to persuade more journeys, business operations and holding of meetings and seminars (Trišić, 2018).

Obstacles: The overall global economy is in a state of recovery from recession, which affects the budget of hosts and exhibitors worldwide. They have to be economical and pay for only what is expected to be worth their investment. However, Lao PDR has poor management of tourism facilities and related services e.g. hotels, restaurants, tourist service centers, toilets and tourist attractions signs (3 languages). It has no specific agency overseeing MICE industry, except the Department of Tourism that mainly focuses on tourism promotion. There is insufficient number of staffs with professionalism and language skills for MICE industry too. In addition, according to Spencer \& Bavuma (2018), several Asia Pacific region countries (namely, China, Korea, Singapore, etc.) use different technologies that are superior to Lao PDR in improving and modernizing event venue and amenities. They develop and diversify tourist attractions to promote the economy as well.

Analysis of Industry Competition Situation of LNCC: it is found that holding of meetings, seminars and exposition in Lao PDR is an important element of MICE and tourism-related businesses. This is due to the fact that their target group including tourists, enterprises and organizations has a high purchasing power. Most of them have a high potentials and qualification; are well educated and hold executive positions. As the marketing lies at the heart of tourism business, the government realizes its importance by devising policies to provide considerable supports in a continual manner. This is an effort to turn Lao PDR into an alternative for organizing events and seminars to generate income (Spencer \& Bavuma, 2018). However, LNCC, which is one part of MICE industry, is affected by certain competitive environment factors (Porter, 1985; 2008) as follows:

1. Bargaining Power of Suppliers: suppliers or food service providers for LNCC have a low bargaining power because there are numerous food and snack providers in Lao PDR. However, the associations, organizations and professional entities involving or organizing meetings, seminars, expositions or trade exhibitions have a bargaining power because the inability of LNCC to provide services according to their demand may lead to their decisions to use the service of other venue with the same capacities and standards. As a result, LNCC 
needs to build a good relationship with food and snack suppliers or providers, professional entities associations and organizations for expanding cooperation networks in order to have more partnering suppliers.

2. Bargaining Power of Buyers: both medium and large hotels can be providers of meeting venue and many of them can be found across Lao PDR and in Vientiane resulting in a high bargaining power of clients or target groups. With regard to the number of qualified and standard hotels in Lao PDR according to star rating in 2019, there are 6, 11 and 23 hotels rated with 5, 4 and 3 stars, respectively. All of them can accommodate medium to large meetings. Therefore, LNCC needs to create a new perception reflecting its added value in terms of professional expertise, standard service, cost saving and client's lower burdens when compared to meetings organized on their own. Furthermore, clients of expositions and trade exhibitions have a lower bargaining power than organizers of meetings and seminars because holding of expositions and exhibitions requires great effort, large venue, amenities and complex coordination with relevant departments.

3. Threat of Substitute Products of Services: a disadvantage of LNCC is that the substitute product can easily be found, especially a venue for a small meeting, seminar, wedding ceremony, exposition or exhibition. The target group of this service is small and specific. On the other hand, it is difficult to find a substitute product for a venue where a large meeting, seminar, exposition or trade exhibition can be held; therefore, clients have to use services of LNCC without other alternatives.

4. Threat of New Entrants or Potential Competitors: this conforms to the study of Jamgade (2018) claiming that the entry of new competitors is difficult because the venue for meetings, seminars, expositions and trade exhibitions require a high investment in terms of location, construction cost, amenities management and staffs with specialized knowledge and skills in management.

5. Intensity of Rivalry among Existing Competitors: the competitive condition of business of the venue for meetings, expositions and trade exhibitions in Lao PDR can be classified on the basis of size and amount of capacity. The competition for the venue of 1,000-2,000 attendees may be low because only a small number of service providers who can accommodate this scale and have amenities in place. Meanwhile, the one of 500-1,000 attendees has a moderate competitive condition since, in Lao PDR, there are more than 5 large hotels with such capacities and amenities. Lastly, a high competition for the venue of not exceeding 500 attendees is found due to the fact that 20 venues including small to large hotels and restaurants are equipped with those capacities and amenities.

\section{CONCLUSION AND RECOMMENDATIONS}

To mange LNCC towards revenue-generating agency and to achieve efficient and full enjoyment of benefit from resources, venue, human resource and budget under the changing direction of highly competitive environment at the national level, LNCC have to use its strengths. This includes the venue's beauty and cultural identity, preparedness of the venue and adjacent areas, amenities and government's budget supports. This is to manage and operate LNCC in accordance with opportunities that arise. The Lao government gives importance to tourism industry investments and gains the acceptance and trust at the ASEAN, Asian and international levels in hosting meetings of alliance group and economic integration blocs. It accelerates infrastructure development by building transport routes for nationwide connection and link with neighboring countries together with the improvement of facilities and utilities to encourage people to travel and to do meeting and seminar business. The competitive landscape assessment reveals the advantages of LNCC in convention center operation. Due to a high investment in construction and facilities management and needs of personnel with 
specialized knowledge and skills in management, LNCC must reduce weaknesses owing to the lack of the following: extension of existing patterns of event organization to the introduction of the latest styles, personnel development and skill enhancement systems or activities to support future growth of LNCC, market opportunity assessment and competitor analysis in making marketing plans and strategies to ensure good image as well as profitable and sustainable operation, recruitment of personnel with managerial expertise and knowledge for management of LNCC and, lastly, professional sales representatives (personnel or agencies) in charge of sourcing and reaching the target market. The grand strategy, activity and program are thus formulated in consistent with the plan for steering operations in the direction that focuses on the use of organizational resources in all activities and works of the organization's units for maximum benefit and achievement of highest effectiveness and efficiency. Besides, executives, those in charge of management, personnel and all stakeholders of LNCC pay attention strategic management, systematic management plan and implementation of strategy with the control before, during and after operations. The results will guide the organization's creation of competitive and sustainable advantages of LNCC in the future.

\section{REFERENCES}

[1] Corbin, J., \& Strauss, A. (2008). Basics of Qualitative Research: Techniques and Procedures for Developing Grounded Theory (3rd ed.). Thousand Oaks, CA: SAGE.

[2] Cresswell, J.W. (2003). Research Design: Qualitative, Quantitative, and Mixed Methods Approaches (2nd ed.). Thousand Oaks, CA: Sage.

[3] Cresswell, J.W. (2009). Research Design: Qualitative, Quantitative, and Mixed Methods Approaches (3rd ed.). Thousand Oaks, CA: Sage.

[4] Creswell, J. W., \& Plano Clark, V. L. (2007). Designing and Conducting Mixed Methods Research. Thousand Oaks, CA: Sage.

[5] Guba, E. G. (1990). The alternative paradigm dialogs. In Guba, E.G. (Ed.). The Paradigm Dialog. (pp.45-57). Newbury Park, CA: Sage.

[6] Grant, R. M. (1991). Porter's competitive advantage of nations: An assessment. Strategic Management Journal, 12(7), 535-548. https://doi.org/10.1002/smj.4250120706

[7] Guest, G., Bunce, A., \& Johnson, L. (2006). How many interviews are enough? An experiment with data saturation and variability. Field Methods, 18(1), 24.

[8] International Association of Conference Centers. (2012). IACC Quality Standards. Retrieved July5, 2018, from http://www.iacconline.org/content/files/QAonline.pdf

[9] International Congress and Convention Association. (2018). 2017 ICCA Statistics Report Country \& City Rankings Public Abstract. Singapore.

[10] International Monetary Fund (2018).2018 Global Meetings and Events Forecast. GBT Travel Services UK Limited.

[11] Jamgade, Sweety. (2018). Scope of MICE Tourism as an Emerging Hospitality Industry.

[12] Lincoln, Y.S., \& Guba, E.G. (1985). Naturalistic Inquiry. Beverly Hills, CA: Sage.

[13] Marshall, B., Cardon, P., Poddar, A., \& Fontenot, R. (2013). Does sample size matter in qualitative research? A review of qualitative interviews in IS research. Journal of Computer Information Systems, 54, 11- 22. doi:10.1080/08874417.2013.11645667

[14] Miles, M., \& Huberman, A.M. (1994). Qualitative Data Analysis. Thousand Oaks, CA: Sage Publications.

[15] Ministry of Information, Culture and Tourism. (2016). Lao PDR. Tourism Strategy 20062020. Laos. 
[16] Office for Promoting Conventions and Exhibitions and the Thai Exhibition Association. (2010). Introduction to exhibiting products. Bangkok: Kittichai Printing.

[17] Office for Promoting Meetings and Exhibitions (2013). MICE industry in Asia. MICE movement in Asia. Bangkok: Office of Convention and Exhibition Promotion. (Public Organization).

[18] Office of the Prime Minister of Lao PDR (2017). Summary of policies and plans for affiliated agencies (2017-2018). Copy documents. Lao PDR: Vientiane.

[19] Pearce, J,. A \& Robinson, R., B. (2007). Strategic Management: Formulation, Implementation, and Control. McGraw Hill: edition 7.

[20] Pearce, J,. A \& Robinson, R., B. (2009). Strategic Management: Formulation, Implementation, and Control. McGraw Hill: edition 8.

[21] Porter, M.E. (1985). Competitive Advantage: Creating and Sustaining Superior Performance. New York: The Free Press.

[22] _ (1990). The Competitive Advantage of Nations. New York: The Free.

[23] Porter, M.E. (2008) "The Five Competitive Forces That Shape Strategy", Harvard Business Review, January 2008, pp. 79-93.

[24] Ramsborg, G. C., Krugman, C., Vannucci, C., Cecil, A. K., Miller, B. L., Reed, B., \& Sperstad, J. E. (2015). Professional meeting management: A guide to meetings, conventions and events: B2 Books, an Agate Imprint.

[25] Spencer, J \& Bavuma, Zimkitha. (2018). How important are mice to the tourism economy?.

[26] Theng, T. (2019). M I C E and Event Management Venue Management. Retrieved on 31 October 2019 from https://www.youtube.com/watch?v=DGsQvA56qZc

[27] Trišić, Igor. (2018). The role of MICE industry in tourism development.

[28] UNWTO (2016). UNWTO Tourism Highlights 2016 Edition. [online] Madrid: World Tourism Organization, pp.12-16. Available at: http://www.eunwto.org/doi/pdf/10.18111/9789284418145 [Accessed 14 Apr. 2017].

[29] Wheelen, T,L., \&, Hunger, J. D. (2012).Strategic management and business policy : toward globalsustainability.13th ed. N.J: Upper Saddle River. 